\title{
MULTIVECTORNESS AS A WAY OUT OF THE IMPASSE OF STRATEGIC VULNERABILITY
}

https://doi.org/10.18485/iipe_balkans_rssc.2020.ch11

Abstract: The Balkans remains a zone of strategic vulnerability aggravated by the struggle of major global political actors for Serbia, a country that has long been trying to preserve a relative political and military neutrality. Despite serious upheavals at the turn of the $20^{\text {th }}$ and $21^{\text {st }}$ centuries, including the dissolution of Yugoslavia, the bombings by NATO, the "divorce" with Montenegro and the creation of the "Republic of Kosovo," Belgrade has been managing to balance between two major poles of attraction - the EUNATO and Russia, which fits into the concept of multivectorness. Given all geographic, historical, cultural and economic determinism of European integration, Serbia's final choice of the European vector is complicated by two sensitive and problematic matters - the need to recognize the "Republic of Kosovo" and the inclusion in the military and political framework of NATO. Moreover, the first issue entails substantial political and civilizational risks, both for the Western Balkans and the European Union as a whole, let alone a dramatic internal split of the Serbian society over the possible recognition of the newly formed independent Albanian entity. On the other hand, Russia, which has unique image opportunities and, unlike the EU, does not aspire to play the role of an "empire by invitation", is a natural counterbalance to the Euro-Atlantic pressure on Belgrade. The situation is further complicated by the fact that the existing historical dualism of multivectorness is being disrupted by the emergence of China, a new player in the Balkans. By solely economic levers, Beijing has been solving the strategic problems of penetration into European markets and simultaneously smoothly, but sequentially superseding Russia as Serbia's main alternative to the West. The article analyzes the tactic employed by Chinese companies and concludes that there has been a growing concealed competition between the People's Republic of China and the Russian Federation for the place of the main non-European actor not only in Serbia but in the Balkans as a whole. In such circumstances, by preserving the policy of multivectorness (despite all criticism of the concept), Serbia may find a way out of the impasse of strategic vulnerability, i.e., to achieve a

\footnotetext{
${ }^{1}$ Professor, Moscow State Institute of International Relations (University) of the Ministry of Foreign Relations of the Russian Federation, Moscow, Russia. E-mail: nastya304@mail.ru.
} 
prospect, if only short-term, of the status quo of political, military and strategic neutrality.

Keywords: Serbia, the EU, Russia, China, NATO, the policy of multivectorness, the Kosovo problem.

\section{INTRODUCTION}

Over the centuries, the Balkans has been a turbulent zone of world politics, which is largely determined by the historical legacy of overlapping cultures, religions, and traditional habitats of its peoples. Currently, the region remains highly prone to instability due to the clashing interests of the leading political actors of today - states, supranational and transnational entities. Some of them are criminal by nature, with the growing activity of representatives of international terrorism (Speckhard and Shajkovci, 2018) and closely-related international criminal world (Benedek et al., 2010).

Today, particular attention of the world community is riveted on Serbia. This middle and the most important country of the Western Balkans occupies a special place in the strategy of Euro-Atlantic integration. The choice of that vector of development is complicated for the Serbian society by a number of highly problematic and sensitive questions. The key matter of principle at stake is the very impossibility for an overwhelming majority of Serbians to accept the territorial and metaphysical loss of Kosovo and Metohija (K\&M), the cradle of the Middle-Ages Serbian statehood.

The attitude to the 1999 bombings by NATO is the second major question. The majority of the Serbian society remains firm: "cannot be forgotten, cannot be forgiven." On the other hand, the political leadership of the country seeks to find a compromise with the alliance within the framework of "ready to forgive, but cannot ever forget."

The lack of consensus on the matters of such significance for the Serbian society is aggravated by the need to make an unambiguous choice between the European and the Eurasian integration models that have been actively articulated by Brussels. Serbian Prime-Minister Ana Brnabić signed the FreeTrade Agreement with the Eurasian Economic Union (EAEU) in Moscow, on 25 October 2019. However, other issues have been troubling Brussels. The Chinese expansion is also fraught with a potential threat to the further development of Euro-Atlantic integration in the region: Beijing views Serbia as the main investment anchor (Conley et al., 2019) as well as the point of attraction (assemblage) of the Balkan limitrophes. 
The above-mentioned processes have been unfolding against the backdrop of NATO's internal imbalance and even "brain death" of the alliance (Briefing, 2019, p. 18), as well as the EU transformation. Therefore, the verdict given by the European greats at the summit of the Western Balkans in Poznan in July 2019 - the EU enlargement is being postponed seems to make sense. The "suspended" political and emotional expectation of a European future does not cancel, however, the "exceedingly strict" requirements from the EU for the potential members of the union. To fulfill them, Serbia, according to Alexandar Vučić, will have "to climb Mount Everest," (Sysoev, 2018, p. 6.), which is naturally bound to affect the social and political climate in the country.

The analysis of the above-mentioned factors in their complexity helped to articulate a hypothesis: a way out of the impasse of strategic vulnerability and preservation of its historical and cultural integrity and a relative (a characteristic applicable even to the world giants amid global interdependence) independence, as well as the significance of the country as an important balance force on the international agenda, require that Belgrade pursue a policy of multivectorness and military neutrality. Having several toeholds (economic, political, military and cultural) opens up new opportunities, and may allow Serbia to preserve its status as an important regional actor.

\section{MULTIVECTORNESS AS A POLICY OF SURVIVAL}

A story by Milorad Pavić called The Wedgewood Tea Set depicts a complex relationship between two characters - a woman and a man whose names are unknown. The story is told by a first-person narrator and finishes in the following way: "Could it be that I actually hated her?.. If the reader has not figured out himself, here is the answer to the riddle. My name is Balkan. Her name - Europe" (Pavich, 2003, p. 366).

The history and the present of interrelations between the Balkans and European countries is fraught with controversy. It would not be an exaggeration to say it is with Serbia that Europe has the most delicate dialogue. Twice in the $20^{\text {th }}$ century (the First and Second World Wars), Serbia found itself in the trenches of the war against Europe of the Second and Third Reich and came out of the battles among the victors. Serbia emerged as the center of the Balkan "empires" - Royal (1918-1941) and Socialist (19451991) Yugoslavia as a geopolitical outcome of the bloodsheds. The destruction of the latter and its consequences proved to be a national tragedy 
for Serbians - they not only suffered a defeat in the Balkan wars of the modern times in Croatia and Bosnia and endured a decade of sanctions and 78 days of the bombings by NATO aviation, but also lost control over Kosovo and Metohija.

The support for Kosovo separatists given by the collective West dramatically upset Serbia's perceptions of its place in Europe, although all Serbians are well aware of the role of the great powers, including the European ones, Austria-Hungary and Italy, above all, in designing the Albanian nation and promoting the concept of "Greater Albania" that came to symbolize the genocide of Serbs during the Second World War. History repeated itself in the new tragedy: the Kosovo problem became the watershed in the Balkan reality and solidified the cultural identity code of the majority of Serbians, as well as their attitude to Great Europe, expressed by M. Pavich in the faraway and cozy year of 1973.

The weak statehood as an outcome of the destruction of the "segmentstate" (Roeder, 2007), within which Serbia "vanished" in the Yugoslavianness and as willed by Marshal Tito, "the last Habsburg in the Balkans," lost a significant part of its traditional territories, engendered Belgrade's strategic vulnerability. Quite limited leeway in domestic and foreign policy disposes Serbia (following the example of most post-Socialist countries) towards choosing to be an "empire by invitation" (Lundestad, 1986) ready on strict conditions to take on the burden of a sponsor and protector.

Unlike other "new democracies", Serbia still avoids the final choice of a patron and seeks to pursue a policy of multivectorness allowing it to balance between the interests of the leading world-political actors. With all its limitations and despite existing criticism, the policy of multivectorness, if it involves an ingenious and shrewd game, allows "small nations" (Colomer, 2007) to protect their interests and diminish foreign-policy dependency to the fullest possible extent. At the same time, a vectorial priority invariably remains. For example, for Central Asian countries, it is Russia and China. For the post-soviet countries of the Caucasus, it is Russia, Turkey and the US. In the case of Serbia, it is the EU.

The European vector is a rational choice for a number of reasons (politics, geography, economy and culture). The approach was formalized in the Stabilization and Association Agreement ratified by the Parliament of Serbia on 9 September 2008. Serbia's President B. Tadić submitted a membership request to join the EU on 22 December 2009. For Belgrade, that moment marked the beginning of the laborious process of fulfilling all the new conditions of both European and Atlantic integration because the EU 
membership was tightly connected with strategic military matters. It may seem that the dual (the EU-NATO) choice to be an "empire by invitation" was made. Belgrade met nearly all the membership conditions, including the normalization of relations with the "Republic of Kosovo" (RK), and signed, in 2015, the Individual Partnership Action Plan (IPAP) - a framework agreement that outlined maximum close cooperation with NATO.

However, things are not unambiguous in the Balkans. With the focus on the EU and NATO, Belgrade has not only maintained but also strengthened the cooperative potential with Moscow, and intensively develops relations with Beijing.

Russia, although it does not aspire to play the role of an "empire by invitation, is a very important counterbalance vector for Belgrade; it is a traditional ally with which Serbia established, in 2013, "relations of strategic partnership embracing politics, trade, economy, culture, science, technology and education" (Deklaraciya, 2013). Taking into account growing tensions in the region, and rising threats to security, special attention is paid to military-technical cooperation.

The nearly religious cult of Russia in general and V. Putin's in particular, which have developed over the last couple of decades, attach a special quality to the Serbian-Russian relations. V. Putin has been the most popular foreign leader in Serbia for many years, with $57 \%$ of Serbians expressing confidence in him, as much as in A. Vučić (Istraživanje, 2019).

Relatively recently, China, another important player, has emerged in the Balkans, its presence marked with purely economic interests for the moment. "For the moment" is key here: economic penetration of Chinese companies and investors into spheres that determine the sustainability of a modern country (infrastructure, agriculture, telecommunication and financial networks) will inevitably lead to political penetration. It is just a matter of time.

The 16+1 multilateral format of cooperation proposed by Beijing in 2012 has given a significant impetus to the relations between Serbia and China ${ }^{2}$. The initiative constitutes a part of China's transcontinental economic and geopolitical vision - the updated version of the Go Out policy intending deeper integration of the country into the world economy, and the ultimate global economic leadership.

\footnotetext{
${ }^{2}$ The 16+1 format broadened in April 2019 to include Greece. The move was accompanied by a sale of the controlling stake in the port of Piraeus to the Chinese COSCO company.
} 
China began the construction of the "Balkan Silk Road" with the flagship investment in the port of Piraeus viewing Greece as the gate to Europe through the Balkans. The Belgrade-Budapest $350-\mathrm{km}$ rapid railroad with a budget of $\$ 2.9$ billion is the second major project. In 2016-2017, the main part of Chinese investments within the Belt and Road Initiative and construction projects (nearly $\$ 1.8$ billion) was given to Serbia to build roads and modernize the energy sector (Zeneli, 2017).

Through economic leverage, Beijing achieves its strategic tasks. Participation in various regional infrastructure and energy project in the Western Balkans will allow Chinese companies to succeed, in the near future, in significantly lowering costs of export of goods to the EU with the mediating role of the Balkan countries that have free-trade agreements with the EU and with economic penetration and consolidation of its positions in the European market. As a result, quite naturally, both the EU and Russia have been increasingly concerned about Chinese penetration in the region. At the moment, there is no direct rivalry between Beijing and Moscow in the Balkans, with each pursuing its own goals that scarcely overlap. Issues emerge in image and positioning, rather than economic matters: China has been gradually and sequentially ousting Russia as Serbia's main alternative to the West.

The role of the United States in the Balkan arena, particularly the Kosovo problem, deserves a special mentioning. Washington has been playing its own game, often in opposition to the policies of Berlin, London and Paris individually, rather than that of Brussels. Serbia's current politicians, as well as opposition representatives, maintain constant contact with American political structures. Nevertheless, it will be a mistake to speak about a US foreign-policy direction of Belgrade. If anything, Serbia has been using Washington to play the card of internal European discord as well as to counterbalance Moscow.

The above-mentioned foreign-policy multivectorness may be seen as a way out (if temporary) of the strategic vulnerability impasse inside as well as outside of the country. The former case has to do with freezing the Kosovo problem and the latter concerns, maintaining the consensus about military neutrality. Taken together, both will allow stabilizing the political situation in the country, win some amount of time, and invest efforts into finding new strategic opportunities. 


\section{KOSOVO: THE MAIN SETBACK IN EUROPEAN INTEGRATION}

The so-called Berlin Process initiated in August 2014 is being stalled by long-standing regional and common European social, economic and institutional problems. French President E. Macron's deliberations, during his visit to Belgrade in July 2019, on the complex process of integrating Serbia in view of the need to "reform the EU" caused little surprise. Currently, neither Brussels nor the Serbian society is particularly enthusiastic about the prospect of Serbia's membership in the EU. For instance, a survey of the youth from the Western Balkans revealed that Albania and Kosovo, $94.5 \%$ and $88.9 \%$ respectively, have the strongest support for joining the EU. They are followed by Bosnia and Herzegovina (84.9\%), North Macedonia $(81 \%)$, and Montenegro (77.2\%). Serbia with $56.1 \%$ holds the last position on the list (Demostat, 2019). It was in January 2018 when the number of those supporting European integration in an all-Serbian survey reached $52 \%$ for the first time (Izvestiya, 2018), but that was a gauge of wishes. At the same time, the path to membership grows more complicated every year with new requirements. The recognition of the Srebrenica genocide may become another one (many countries in the EU and Switzerland have already adopted a law on criminal sanctions for its denial). However, that is a prospect. Today, the fate of the Serbian province of $\mathrm{K} \& \mathrm{M}$ is the main obstacle on the road to resume European integration.

The Kosovo problem is the most sensitive for Serbia. Tensions over the self-proclaimed entity have risen due to the so-called "demarcation/ compromise" project. The idea, which was initially proposed at a high level by Ivica Dačić a few years ago in Zëri magazine published in Albanian, that Serbs should stay in Serbia while "the other part where Albanians reside is to be severed" (Dačić, 2011) transformed into a project of territorial exchange. The demarcation topic entered the modern political discourse in 2018: it is somewhat associated with the name of Oliver Ivanović (a Serbian politician killed on 16 January 2018) who promoted the so-called Cyprus model to resolve the Kosovo problem.

Initially, the main issue was which territories specifically would take part in the exchange. Belgrade and Pristina worked out two plans. Even respective maps were prepared based on the agreements reached by Thaçi and Vučić at the European Forum in Austria in August 2018. Thaçi insisted on the "package" plan that involved a complex territorial exchange: the Serbian communities of Leposavić, Zvečan and Zubin Potok (approximately $1 / 5$ of the K\&M territory) would go to Serbia; the southern Serbian communities of Bujanovac (55\% ethnic Albanian population) and Preševo 
(89\% ethnic Albanians) would be part of the RK. Serbia's leader was adamantly opposed to "automatically" including the southern Serbian communities of the Preševo valley into the exchange (Bondarenko, 2019, p. 11). Nevertheless, an agreement was assumed to be signed in early September 2018 in Brussels.

The mere possibility of transfer to Pristina of some Serbian territories provoked a significant concern in the country (many-month protests demanding Vučić's resignation and an early parliamentary election); generated a political split in the RK (Thaçi vs Haradinaj), as well as escalated disagreements within the EU. Angela Merkel strongly opposed the territorial exchange. Vienna expressed unequivocal support for the transfer of territories, which is a logical continuation of Austria-Hungary's policy of constructing an Albanian nation "to use it as a shield against the advance of Greater Serbia" (Toleva, 2018, pp. 500-501).

Nevertheless, it was not the position of the EU and central European countries that played a decisive role in freezing the negotiations and, essentially, led to the removal of the demarcation idea from the agenda. The leadership of Pristina and Tirana agreed on a "common strategy to unite Albanians by 2025" (Vučić, 2018). The growing ambitions of Kosovo Albanians postponed for an indefinite period the prospect of signing a "legally binding agreement" on normalizing the relations between Belgrade and Pristina.

The "Republic of Kosovo" is a heightened danger zone and not only for the Western Balkans but for the entire Europe, which is explained by the irredentist activity of Albanians. In the latter case, the threat stems from the heavy participation of the Albanian segment in international terrorist structures (Ponomareva and Dimitrovska, 2018). A report published by the Department of State notes that Kosovo contributed the highest percentage of militants per capita within the ranks of ISIS (Country Reports, 2018).

Thanks to the EU and the US, Pristina has been given free rein unprecedented for the Balkans. As a result, the centuries-old balance between different peoples that inhabit the region has been offset. M. Gefter defined the situation as "space of absence" that allows finding "space of expansion" (Pavlovskij, 2015, p. 10). Interestingly, it is not only the southern part of the Balkans (as a matter-of-course) but Europe as a whole that constitutes today the space of expansion for the Albanian segment.

The threat that the region poses sets up a new political agenda. By November 2019, as many as 15 countries have recalled their formal recognition of the RK as unduly prompt and violating provisions of the 
Helsinki Accords and Resolution 1244 of the UN Security Council. That seems to be just the beginning of the repulsa consulatus process.

The diplomatic war over the RK's independence has been unfolding amid growing concern of the EU member-countries over the terrorist threat the region constitutes. For instance, the Alternative for Germany expressed alarm at the problem, and an overwhelming majority of the Dutch Parliament voted for the return to a visa regime for Albanians in April 2019 due to the rising crime rate. Against this background, the pressure on Serbia to recognize the RK appears counterproductive not only for the sake of the letter and spirit of European integration. Also, it is yet another argument for departing from the patronage of the dual (the EU-NATO) "empire" and for choosing a multivector foreign policy.

\section{SERBIA AND RUSSIA: OPPORTUNITIES FOR AND LIMITS TO COOPERATION}

The relations between Russia and Serbia are an entire universe. The relations between Russia and Serbia have always developed based on broad mutual understanding and have been marked by warmth, although not without periods of some estrangement and even enmity. The latter took place amid the emergence of fundamentally new social and political systems when Serbia formed the nucleus of the Royal and Socialist Yugoslavia, while Russia was the driving force of the Soviet project.

Since the breakup of Yugoslavia, the position of Russia has been characterized by pronounced Serbophilia although a lot of decisions, looking back from the distance of several years, seem hasty and strategically illconsidered. For example, the analysis of deciphered records of conversations between Bill Clinton and Boris Yeltsin from April 1996 to December 1999 allows arguing there was a possibility of an alternative scenario in March 1999 and an alternative solution to the Kosovo problem (Declassified Documents, 2018, pp. 432-436). Nevertheless, Russia of the 1990s is for Serbians associated with the battle march to capture the Slatina Airport and the moral and psychological support of the Russian society for the Serbian resistance activities, rather than with Yeltsin's disgraceful decisions. Today's Russia upholding the principles of Resolution 1244 of the UN Security Council is regarded in Serbia as the main defender of the republic's territorial integrity.

Since 2013, the Russian-Serbian relations have acquired a new quality. The Declaration on Strategic Partnership has not only opened up new 
opportunities but also has been defining certain frameworks of the relations. Particularly, such a partnership implies shared assessments of the global transformations; aspirations for constructing a "more just and democratic order based on a collective footing and the rule of international law" (Deklaraciya, 2013). It must be admitted, nevertheless, that the strategic partnership 'en Russe', unlike the agreements with the EU and NATO, does not commit Belgrade to institutionally binding moves. Such an approach gives tremendous advantages. At the same time, it does not allow Russia not only to act as a patron but even to designate its strategic and tactical interests.

Military and military-technical cooperation is a special sphere of strategic partnership.

Since 2012, the Russian-Serbian Humanitarian Center (RSHC) has been working in the city of Niš in which Western experts have been trying their best to discern a Russian military base. In fact, the RSHC is a non-profit organization with a dozen full-time employees in charge of prevention and relief of emergency situations. The Center staff members, unlike NATO representatives, do not enjoy diplomatic immunity.

Russia is a major donor for the Serbian army. Serbia's Armed Forces received on a gratis basis six MiG-29, 30 BRDM-2MS armored patrol and reconnaissance vehicles, and 30 T-72 MS tanks. To that, one should add significant discounts and other preferences when it comes to receiving Russian armament and military equipment. The modernization of Serbia's army is "a guarantee that the Balkans will be at peace, especially in the context of the formation of paramilitary units in the RK" (M. Vulin).

Belgrade thinks that its policy of military neutrality promotes lasting peace in the Balkans, although it is unrecorded in the country's fundamental documents - the Constitution and the Defense Strategy. The National Assembly Resolution of 26 December 2007 represents the only institutional framework of military neutrality. Moreover, "a final decision on the matter" is to be made in a referendum. And although a referendum has not been held yet, that does not cancel the declared status and gives the country a chance to develop cooperation with both Russia and the structures of the alliance.

The prospect of preserving Serbia's neutrality depends on many factors. Firstly, freezing the negotiation on recognizing the RK. Fitting together the Kosovo problem and the status of the Republic of Srpska seems advantageous for Serbia.

Secondly, the radicalization of Pristina's domestic and foreign policy. Given that the radicals and advocates of the Greater Albania project (A. 
Kurti's Self-Determination, I. Mustafa's Democratic League) came to power through the 6 October 2019 parliamentary election, it is significantly easier for Belgrade to develop the tactic of impeding the negotiations. Against this background, the attention of the world media to Albania and the RK as special zones of international terrorism and criminal may have an impact on changing the public opinion in Europe and the world.

The successful growth of strategic partnership is possible with a clever combination of conventional and unconventional approaches. For example, the demand for education in Russia has been traditionally high in Serbia. The high price and lack of grant programs common in Western and Chinese universities are the main limitations. The decision to give grants to Serbian students is made at the level of the Russian President (!). 120 grants were given for the 2019 academic year, while in 2016, there were 85 . The political conjuncture will determine the allowance for 2020, 2021 and later on. Amid growing competition for Serbian students, the Russian Federation may once again lose unless it puts forward a comprehensive program of cooperation not only with Moscow's giants (agreements between MSU and MGIMO with the University of Belgrade) but also with regional universities. To achieve maximum efficiency of the partnership, the educational strategy is to be enhanced by technologies that produce results in the short run. These are the media sphere, cinematography, sport and social diplomacy content (non-profit organizations).

Drawing an intermediate conclusion, the following is to be noted. Russia, despite its obviously small economic resource, maintains a considerable scope of influence (the country accounts for only $4 \%$ of trade volume, International Trade, 2018) compared to the EU and China. The demand for its initiatives is persistently high. The fact that Russia lacks a long-term comprehensive and clear-cut program is the main constraint on the development of the strategic partnership. Many initiatives are born ad hoc and are not supported by the necessary social, economic, and political infrastructure.

\section{CONCLUSION}

The conducted analysis revealed three key vectors of development of today's Serbia. Euro-Atlantic integration, which, despite the apparent decline, remains Belgrade's priority since the 2000s, is the first vector. The choice of the EU as an "empire by invitation" that requires recognizing the RK and joining NATO demonstrates only the following: "the attitude of the Balkans 
to Europe and vice versa - Europe to the Balkans - is the cross-cutting clash of the region's life and the reason for abrupt zigzags of its history and present day" (Vishnyakov and Ponomareva, 2018, p. 119).

The Russian direction defined by cultural, historical and political rather than economic factors is the second balancing vector. However, maintaining the presence in the region requires that Russia should invest great effort and put forward proposals for a new agenda. Implementing such an approach implies a clear-cut definition of Russia's national interests in the region and understanding its foreign-policy goals. That, in turn, is only possible with a comprehensive audit of resources, methods and technologies of power.

China is the third vector. While the actors traditionally present in the Balkans refer to history and develop geopolitical strategies, China is stepping up its presence by exclusively economic means. Serbia and other Balkan countries find Beijing valuable due to its financial and fast-speed attractiveness (decisions on the launch of projects are made swiftly) as well as its political neutrality. Chinese companies are willing to work with both "philes" and "phobes", whatever part of the world their roots belong. China is "entering" the Balkans having a strategy as well as fulfilling tactical tasks. The former involves further Chinese expansion in Europe by modernizing old and constructing new ports and other infrastructure within the Belt and Road Initiative. The tactic is developing the Serbian and Balkan markets, including the end market.

It is China, rather than the EU, that appears to be able to integrate Europes of "different speeds": the financial support for multilateral formats of the European South; industry- and logistics-specific investments largely in energy, transport and telecommunications infrastructure in the main crossroads of the region (ports, railroads, frontier cities) allow Beijing to be the "coordinator" of key economic processes that, in turn, lay the foundation for new political decisions.

The carried-out research verified the hypothesis: multivectorness for Serbia is a policy of ending the impasse of strategic vulnerability. Having several toeholds (economic, political, military and cultural) will not only allow Serbia to preserve the status quo in the most sensitive - Kosovo problem and thus indefinitely postpone the incorporation into the military and political framework of NATO, but also to consolidate its status of an important regional actor and to protect its global political subjectivity. 


\section{REFERENCES}

Benedek, W., Daase, C., Dimitrijevic, V. \& van Duyne, P. (2010). Transnational Terrorism, Organized Crime and Peace Building. Human Security in the Western Balkans [E-Reader Version]. Retrieved from http://cn4hs. org/wp-content/uploads/Human-Security-in-the-Western-BalkansBenedek-et-alled.chp12.pdf. Accessed 28 December 2019.

Bondarenko, O. (2019). Rossija i Serbija na povorotah istoriji [Russia and Serbia at the Turns of History]. Moscow, Veche.

Briefing Macron's view of the world (2019, November 9). The Economist, pp. 17-20.

Blic. (2018). Vulin: Vojska Kosova pretnja za mir i stabilnost na Balkanu [Kosovo Army threatens peace and stability in Balkans]. 13.03.2018, retrieved from https://www.blic.rs/vesti/politika/vulin-vojska-kosova-pretnja-za-miri-stabilnost-na-balkanu/m2spq01. Accessed 05 January 2020. (in Serb.)

Conley, H., Hillman, J. \& Melimo, M. (2019, July 30). The Western Balkans with Chinese Characteristics, retrieved from https://www.csis.org/ analysis/western-balkans-chinese-characteristics. Accessed 25 November 2019.

Colomer, J.M. (2007). Great Empires, Small Nations: The Uncertain Future of the Sovereign State. London-New York, Routledge.

Country Reports on Terrorism (2018, September), retrieved from https://www.state.gov/reports/country-reports-on-terrorism-2017/. Accessed 28 November 2019.

Dačić nije tražio podelu Kosova! [Dachic did not ask for the division of Kosovo!] (2011, October 10). Istinomer, retrieved from https:// www.istinomer.rs/ocena/1375/Dacic-nije-trazio-podelu-Kosova. Accessed 28 November 2019.

Declassified Documents Concerning Russian President Boris Yeltsin (2018, July 13), retrieved from https:/ / clinton.presidentiallibraries.us/items/ show/57569. Accessed 28 November 2019.

Deklaraciya o strategicheskom partnyorstve mezhdu Rossijskoj Federaciej i Respublikoj Serbiej [Declaration on strategic partnership between the Russian Federation and the Republic of Serbia] (2013, March 24), retrieved from http://www.kremlin.ru/supplement/1461. Accessed 28 November 2019.

Demostat (2019, May 13). Više žele u Evropu nego da im zemlja uđe u EU [They more want to go to Europe than EU membership of the country], 
retrieved from http://demostat.rs/sr/vesti/istrazivanja/vise-zele-uevropu-nego-da-im-zemlja-ude-u-eu/660. Accessed 25 December 2019.

International Trade Centre (2018), retrieved from http://www.intracen. org $/$ layouts $/$ CountryTemplate. aspx?pageid $=47244645034 \&$ id $=4724465$ 2579. Accessed 25 December 2018.

Istraživanje: Vučić ubedljivo najpopularniji političar [Research: Vucic is convincingly the most popular politician] (2019, January 3). Večernje novosti [Evening news], retrieved from http://www.novosti.rs/ vesti/naslovna/politika/aktuelno.289.html:769462-Istrazivanje-Vucicubedljivo-najpopularniji-politicar-Putinu-najvise-poverenja-medjusvetskim-liderima. Accessed 25 December 2018.

Izvestiya [Izvestia Newspaper] (2018, January 23), retrieved from https://iz.ru/699298/2018-01-23/bolshinstvo-uchastnikov-oprosa-vserbii-vyskazalis-za-vstuplenie-v-es. Accessed 25 December 2018.

Lundestad, G. (1986). Empire by Invitation? The United States and Western Europe, 1945-1952. Journal of Peace Research, 23(1), pp. 263-277.

Pavich, M. (2003). Lovcy snov [Dream Hunters]. Saint-Petersburg, Azbukaklassika.

Pavlovskij, G. (2015). Sistema RF. Istochniki rossijskogo strategicheskogo povedeniya: metod G.F. Kenan [System of the Russian Federation. Sources of Russian strategic behavior: G.F. Kenan method]. Moscow, Evropa.

Ponomareva, E. \& Dimitrovska, A. (2018). Balkanskij uzel mezhdunarodnogo terrorizma [The Balkans junction of international terrorism]. Obozrevatel'-Observer, (5), pp. 37-51.

Roeder, Ph.G. (2007). Where Nation-States Come From: Institutional Change in the Age of Nationalism. Princeton, Princeton Univ. Press.

Speckhard, A. \& Shajkovci, A. (2018). The Balkan Jihad. Recruitment to Violent Extremism and Issues Facing Returning Foreign Fighters in Kosovo and Southern Serbia. Soundings, 101(2), pp. 79-109.

Sysoev, G. (2018, February 12). ES rasshiryaetsya na Balkany [The EU is expanding into the Balkans], Kommersant, pp. 1-6.

Toleva, T. (2018). Avstro-Vengriya i stanovlenie albanskoj nacii [Austria-Hungary and the formation of the Albanian nation]. Moscow, Institut slavyanovedeniya.

Vishnyakov, Y. \& Ponomareva, E. (2018). Serbia in the Balkans: The Invention of 'Europe's Gun poeder Magazine'. Contemporary Europe, (7), pp. 108-121. doi: http:/ / dx.doi.org/10.15211/soveurope72018115129 
Vuchic, M. (2018, November 28). Šta su Haradinaj i Rama (do)govorili u Peći? [What did Haradinaj and Rama agree in Peć?], Raskrikavanje, retrieved from https://www.raskrikavanje.rs/page.php?id=320. Accessed 25 December 2018.

Zeneli, V. (2017, November 25). What Has China Accomplished in Central and Eastern Europe? The Diplomat, retrieved from https:// thediplomat.com/2017/11/what-has-china-accomplished-incentraland-eastern-europe/. Accessed 25 December 2018. 